\title{
The Influence of Learning Coding Interest on Learning Outcomes of Web Programming and Mobile Devices Subjects
}

\author{
Zahrotun Nafidah ${ }^{1}$, Ghanis Putra Widhanarto ${ }^{2}$ \\ \{nafida.zahrotun@gmail.com ${ }^{1}$, ghanisputra@mail.unnes.ac.id ${ }^{2}$ \} \\ Universitas Negeri Semarang, Semarang, Indonesia ${ }^{12}$
}

\begin{abstract}
Digital startup in indonesia is going rapidly, it caused the need for reliable programmers in challenging of 21 st century competences. However, these are not yet fulfilled due to the low interest of students in learning coding. The purpose of this study was to find out how much the influence of learning coding interest on student learning outcomes in the subjects of Web Programming and Mobile Devices conducted at SMK Negeri 8 Semarang. The method used was quantitative research with the type of ex-postfacto research. The population of this study was class XI Software Engineering students totaling 106 students. The study sample was 35 students of class XI Software Engineering 3 using cluster random sampling and data analysis techniques using simple linear regression. The results of the study showed that the learning coding interest variable had a contribution of $43.90 \%$ to changes in the variables of student learning outcomes, while the remaining $56.10 \%$ was affected by other factors not mentioned in this study. The results of this study are expected to be used as a reference and then followed up in the future learning process in order to improve learning outcomes in related subjects so that the needs of reliable programmers can be fulfilled.
\end{abstract}

Keywords: Learning Outcomes, Mobile Devices, Web Programming, Coding Interest.

\section{Introduction}

The use of digital technology in this increasingly modern era has begun to enter all aspects of human life around the world is no exception in Indonesia. One of the most noticeable phenomena is the start of a flourishing digital startup that thrives. In other words, the use of digital technology is indispensable in any business world.

Creation and development of the digital business, of course, requires a qualified programmer who is capable of mastering coding. Coding itself is the process of translating the design into a language that can be understood by the computer [27]. So, in this case, a programmer must have a high thought logic in realizing a design. Though, Indonesia's human resources who are able to answer the challenge as a reliable programmer has not much, even tend to be less interested in plunging into the field of coding.

Microsoft reported a survey in 2015, majority of students in Indonesia were aware that learning coding in education have benefits and great potential for their future. Those, only 51 percent of students say they have the opportunity to learn to code at school, either as a core subject as well or as an extracurricular activity [13]. 
It shows that 51 percent of students who have learned opportunities are expected to be a reliable programmer in the future. In other words, the remaining 49 percent of students who can study at school have not been known to be interested in coding materials.

Software Engineering is one of the majors in Vocational High School that includes coding through one of the subjects that is web programming and mobile. With the competence of this web programming, the graduates are expected to be able to meet the challenges and needs that are relevant to the industry and of course so that through the coding of Indonesian children can go faster and compete with children from other countries as a statement from the Minister of Communication and Informatics (Menkominfo of Indonesia) [11]. In this case, the abovementioned goals can be achieved through a learning process.

Learning is an activity that is geared toward a particular purpose, which is the purpose of learning itself to be required to have a centralised attention and interest as a condition that the process takes place well and has a result that expected [21]. Therefore, interest does understand as a state of psyche or psychology that causes directional and the center of attention to an activity that is happening faced include the subject.

The fact obtained in the field especially in the Software Engineering Department of SMK Negeri 8 Semarang is still lack. It shows that there are still students who feel wrong to choose a course and do not know that the software engineering majors are closely related to coding material and this ultimately causes them to be less interested in learning Web programming, because they already have the thought that coding is a difficult thing to understand because it requires mastery of logical thinking. Moreover, they will often find the word "error" when coding process is being done, because of that, the learning outcomes achieved by the class XI Software Engineering students tend to be uneven because there are still some students who often do remedy because their exam results were not reach the MGM (Minimum Graduation Criteria).

Community demands for vocational high school graduates should be considered. Therefore, the learning process in schools should use effective methods to produce graduates that fit the needs of the industry. It is also the reason why the study at vocational high school is more emphasis on things that are practical than the theory.

In theory, practice-based learning is a method by providing educational materials using tools or objects, such as demonstrated, with the expectation that the students become clear and easy to be able to practice the material in community. This method provides the way for learners to apply, test and adapts the theory to the real condition through practice or work; this is a practice or practice participant will get an excellent lesson to develop and perfect the skills required [22].

This practice-based learning can run smoothly when active learning is designed. Active learning is one type of learning approach that puts learners as an active subject and has the readiness to study [3]. In this case, it means that active learning makes learners as a subject of learning so that it has the potential to increase the creativity of learners and is also more active in every given lesson activity.

It is following the opinion, active learning is a broad umbrella term to describe courses where students are actively constructing their knowledge as opposed to listening passively [2]. In other words, it shows that active learning is a container for students to be able to build their knowledge as opposed to passive listening, such as working between students during the class.

How to empower learners are not only by using a strategy or method of discourse alone, as used by the educators (teachers) in the learning process. Educating with the lecture means providing information through hearing, which can only digest the brain of $20 \%$ of students. Whereas the information students learn could be from reading (10\%), seeing (30\%), seeing and 
hearing (50\%), saying (70\%), saying and doing (90\%). It is following the opinion of a confucian philosophy that "what I heard, I forgot" "What I see, I remember" "What I do, I understand" [3].

Based on the statement above, active learning can be created when every individual of students has a learning interest so that it is finally able to practice what has been received. Individual interest in this may be defined as a psychological state characterized by focused attention, improved cognitive and affective functioning, and persistent effort, which can be seen as an individual's tendency to pay attention to specific stimuli, events, and objects-including school subjects [26].

The learning outcomes are the level of statements achieved by students in following the learning program following the educational objectives established [9]. In this case, The learning outcomes describe the skills, abilities, knowledge, or measurable values that students must collect after completing a program [12].

The purpose of learning according to Sugandi is to assist students in obtaining various experiences, and with that experience, the behavior in question includes the knowledge, skills, and values or norms that serve as attitudes and behavior controllers [3]. Success or absence of learning objectives can obtain seen from the learning outcomes obtained by students so that it remains hoped that good learning outcomes will demonstrate the level of students ' ability in the field of coding.

One of the factors that influence student learning outcomes is psychological factors, including interest, motivation, intelligence, memory, and emotion. A less conducive learning process and a low interest in learning will influence student learning outcomes in web programming and mobile. It is because of the lack of teachers process of classroom experience in guiding the class and the role of parents and friends around him [15]. It is worrying that students' learning achievement is low and not achieving three areas of education (cognitive, affective, and psychomotor).

Interests can affect a person's learning quality in a particular field. When learners have a big interest in coding, the learners will focus much on the subject's eyes closely related to coding, exceeding other subjects. Learning programming will be boring and difficult if they are not interested in the subject. The way the teachers conduct the class also can be a factor that makes the student not interested in the subject. Different students have different types of motivation. Some students motivated to learn to program because of their interest while their parents or friends motivated the others.

Each subject has its appeal for students to learn, all depending on the factors that affect students in learning. The research that the authors do here has an element of novelty from previous studies that lie in the target and type of competency studied that is about web programming and mobile devices that are productive subjects or subjects based practice.

In understanding the emerging issues related to interest, it is necessary to research how much interest in learning coding influence the student's learning outcomes. So later this research can be understood and followed up in the learning process ahead to improve the learning outcomes in Web programming subjects and mobile devices through fundamental analysis of an interest aspects in each student so that the needs of reliable programmers can be fulfilled especially in Indonesia. 


\section{Method}

This research was used a quantitative method with ex-post facto approach. The ex-post facto is conducted by measuring the things that have taken place in the context of the current time without performing the manipulation of the variables examined [19]. The exact thing about this type of research is that researchers do not start the process from scratch, but immediately see the results. From the results, the researchers tried to find the causes of the phenomenon.

Another term of ex-post-facto research is the research after activity, and some also call it comparable causal research. The study aims to compare two or three events that have occurred through causal relationships by searching for the causes of events based on observations that may be seen and observed [18].

This research conducted at SMK Negeri 8 Semarang in Jalan Pandanaran 2 No. 12, Mugassari, Semarang Selatan, Kota Semarang, Jawa Tengah, 50249. The population in this study was the entire class XI student of Software Engineering in SMK Negeri 8 Semarang years lesson 2018/2019 with a total of 106 students consisting of 3 classes. The population was a generalized region consisting of objects/subjects that have certain qualities and characteristics set by researchers to learn and then pulled in conclusion. The population, in this case, is not just the amount that is in the object/subject studied but covers the overall characteristics/properties possessed by the object/subject.

The sampling technique used in this study was clusters random sampling, where sampling was based on a group of individuals and not taken individually [14]. Samples were taken by way of a raffle, so selected one class with the entire student in it as a sample. In this case, samples were taken by a class of XI Software Engineering 3 clas,s with a number of 35 students.

The variables in this study consist of two, i.e., independent variables (variable free) and dependent variables (variable bound). A free variable is a variable that affects another variable, while a bound variable is a variable that is affected or becomes the result of a free variable. The free variable, in this case, is the interest in learning to code while the resulting variable is the result of learning in web programming and mobile devices subjects.

The data collection methods used in this study were a questionnaire, tests, and documentation. The questionnaire used by researchers was a closed questionnaire or close poll to measure the learning coding interest of students variables. A closed questionnaire is a question or statement given to the respondent with the answer that has been provided and does close so that the respondent only chooses the answer that has been provided by the researcher [17].

While the tests used were multiple choice-shaped tests to measure student learning outcomes on the subjects of web programming and mobile devices. The test measurements can continue generated values that symbolize the behavior conduct or performance of testee [23]; which compared to the results of achieved by another testee or compared to a specific standard amount.

The documentation techniques used to search for data on matters or variables in the form of records, training, books, newspapers, magazines, inscriptions, meetings, legger, agenda, etc. [7]. This method was used to retrieve the number of students and student data of XI Software Engineering classes and documentation of learning interest in coding and learning outcomes of the web programming and mobile devices subjects.

The data analysis technique conducted in this study used a simple linear regression analysis method that discusses the relationship between two variables (X and $\mathrm{Y}$ ) in the form of one-way relationship or better known as the functional relationship shaped linear relationship. The word 
linear means that the relationship between the two variables examined is straight-line. The simple word means that there are only two variables researched, no more [10].

\section{Result and Discussion}

The research was conducted from March to April 2019 with respondents of 35 grade XI Software Engineering 3 SMK Negeri 8 Semarang. The results of the research that will be outlined in this chapter are about how much interest influence learning coding towards the learning outcomes of WEB programming and mobile. The overall data of the research results were analyzed using the help of SPSS 21 program by first using a regression prerequisite test, which includes normality test, heteroscedasticity test, and linearity test for later tested hypotheses.

The study analyzes whether variable $X$ (the interest of learning coding) has a contribution in generating correlation to the variable $\mathrm{Y}$ (learning outcomes) where there is or whether the relationship between the two variables can be known through the test Hypothesis. The questionnaire that the authors spread in this study was aimed at students of the XI class of software engineering with 35 samples from across the population to obtain data on student learning outcomes through 20 questions of multiple choice tests..

To find out the learning coding interest of students in the web programming and mobile devices subject, researchers gather data and also the presentation of data from the distribution of polls through tabulation systems in the form of tables. The poll that researchers spread about learning coding interest contained 22 items statements.

Table 1 Descriptive statistical variables research

\begin{tabular}{ccccc}
\hline Variable & Min & Max & Mean & $\begin{array}{c}\text { Std. } \\
\text { Deviation }\end{array}$ \\
\hline $\begin{array}{c}\text { Coding } \\
\text { interest }\end{array}$ & 41 & 95 & 73,57 & 14,849 \\
$\begin{array}{c}\text { Learning } \\
\text { outcomes }\end{array}$ & 35 & 90 & 68,57 & 14,172 \\
\hline
\end{tabular}

Based on the results of the descriptive analysis of the research variables in table 1 showed that the interest in learning coding (X) students of SMK Negeri 8 Semarang has the lowest score of 41 and the highest score is 95 . As for the average learning interest coding students score is 73.57, which belongs to the category of medium with the standard deviation of 14.849 . This means that if you are in contact with an average learning coding interest of 73.57 , then the interest in coding learning will range between $73.57 \pm 14.849$.

While the result of learning (Y) students of SMK Negeri 8 Semarang has the lowest score of 35 and the highest score is 90 . As for the average learning, results score the subjects of web programming, and mobile device students were 68.57, which belongs to the high category with a standard deviation of 14.172. This result indicates that if it is about the average learning result of 68.57 , then the learning results will be ranged in the figure between $68,57 \pm 14,172$. 
Table 2 The result of normality test

\begin{tabular}{llll}
\hline Data & \multicolumn{3}{l}{ Shapiro-Wilk } \\
\hline & Statistic & df & Sig. \\
Coding Interest & .949 & 35 & .102 \\
Learning Outcomes & .957 & 35 & .183 \\
\hline
\end{tabular}

Test normality aims to test whether, in the regression model, the residual variable (bully) has a normal distribution. Accroding to the table 2, the researcher used the Shapiro-Wilk test because of $\mathrm{N}<50$. Shapiro-Wilk Calculation Results on learning coding interest variable obtained a score of Sig. 0.102 , which means more significant than the equivalent of $5 \%$ significance or Sig. $0.102>$ T.S. 0.05, so it can be concluded that the data distribution of learning coding interest is in a normal distribution, as well as the variable of learning outcomes obtained the score Sig. $0.183>0.05$, so it can be concluded that the data was With normal distribution.

Table 3 The results of Heteroskedastisity test

\begin{tabular}{cccccc}
\hline Model & \multicolumn{2}{c}{$\begin{array}{c}\text { Unstandardiza } \\
\text { tions } \\
\text { Coefficients }\end{array}$} & $\begin{array}{c}\text { Std. } \\
\text { Coef. }\end{array}$ & t & Sig. \\
\cline { 2 - 4 } & $\mathrm{B}$ & $\begin{array}{c}\text { Std. } \\
\text { Error }\end{array}$ & Beta & & \\
\hline (Cons) & 14,29 & 5,510 & & 2,594 & .014 \\
& 3 & & & & \\
Coding &,- 081 & .073 & -188 & $-1,097$ & .281 \\
interest & & & & & \\
\hline
\end{tabular}

Heteroskedasticity tests are used to determine whether the variance of data in each variable is homogeneous or not. The calculation result on the regression equation with the Glejser test in table 3 indicates that the significance value (Sig.) for variable $X$ (the interest in learning coding) is 0.281 which is where the significance value is more significant than 0.05 . So in accordance with the basic decision making in the Glejser test, it can be concluded that the regression model does not occur heteroskedasticity.

Table 4 Results of linearity test

\begin{tabular}{cccccc}
\hline & Sum of 2 & df & Mean2 & F & Sig \\
\hline Linearity & 2979.161 & 24 & 124.132 & 1.308 & .351 \\
\hline
\end{tabular}

Based on the results of the analysis of linearity in table 4 indicate that the value of GIS. Deviation from linearity is $0,351>$ Signification level 0.05 , it can be concluded that the model regression model that is a linear specification that there is a relationship between the interest of learning to code and the students ' learning outcomes.

This study hypothesizes that there is a growing interest in learning to code for students learning outcomes in web programming and mobile devices subjects as $\mathrm{H} \alpha$. As for Ho (the Zero hypothesis) is that there is no interest in learning the coding of student's learning outcomes in WEB programming and mobile device subjects. This hypothesis test uses the SPSS program with a correlation coefficient test to figure out the influence between variables. 
Table 5 Result simultaneous significance test (F statistic tests)

\begin{tabular}{cccccc}
\hline Model & Sum of 2 & df & Mean2 & F & Sig \\
\hline Regression & 2995.244 & 1 & 2995.24 & 25.78 & $.000 \mathrm{a}$ \\
& & & 4 & 5 & \\
Residual & 3833.328 & 33 & 116.161 & & \\
Total & 6828.571 & 34 & & & \\
\hline
\end{tabular}

The result of ANOVA's calculations in table 5 obtained information about the calculation result of F of 25.785 and Probability (Sig.) 0.000, which means smaller than the equivalent of 0.05 significance, or Sig. $0,000<0.05$, so that it can be taken to decide that Ho was rejected. It can, therefore, be concluded that the learning of coding interest affects student learning outcomes.

Further correlation analysis results to know the contributing influence of interest learns to code to student learning outcomes. Are presented in the following table:

Table 6 Correlation coefficient test result

\begin{tabular}{ccccc}
\hline Model & R & R2 & Adj. R2 & $\begin{array}{c}\text { Std. Error } \\
\text { of Est }\end{array}$ \\
\hline 1 & .662 & .439 & .442 & 10.778 \\
\hline
\end{tabular}

The correlation coefficient test results in table 6 are shown in the Model Summary table. The table shows an $\mathrm{R}$ score of 0.662 , which means the correlation between learning and coding interest with student learning outcomes is strong. In the Model Summary table is also shown the $\mathrm{R}$ Square of 0.439 . This summary means that the influence of the interest variable influences the learning of coding on students ' learning outcomes by $43.90 \%$, while the remaining $56.10 \%$ is influenced by other variables not covered in this study.

Table 7 Individual Parameter significance test results (T statistics test)

\begin{tabular}{cccccc}
\hline Model & \multicolumn{2}{c}{$\begin{array}{c}\text { United. } \\
\text { Coefficients }\end{array}$} & $\begin{array}{c}\text { Std. } \\
\text { Coef. }\end{array}$ & t & Sig. \\
\cline { 2 - 5 } & $\mathrm{B}$ & $\begin{array}{c}\text { Std. } \\
\text { Error }\end{array}$ & Beta & & \\
\hline (Cons) & 22.06 & 9.338 & & 2,363 & .024 \\
& 7 & & & & \\
\hline $\begin{array}{c}\text { Coding } \\
\text { interest }\end{array}$ & .632 & .124 & .662 & 5.078 & .000 \\
\hline
\end{tabular}

The table 7 provides information about the regression equation i.e. $\mathrm{Y}=22,067+0,632$. Information is also obtained that both the constant score (Sig. 0.024) and beta (Sig. 0.000) are smaller than the level of significance of $5 \%(0.05)$.

The next step is to test the significance of the regression using test-t to test the hypothesis that has been formulated. 


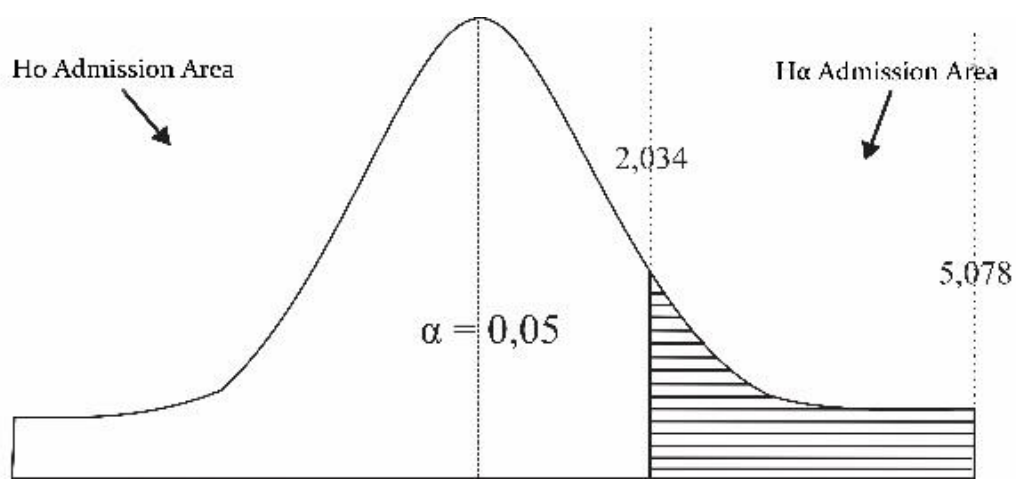

Figure 1 Significant test of one right party

Based on figure 1, it is revealed that $\mathrm{T}$ count (5.078) is larger than the $\mathrm{T}$ table (2.034) with a significance level of $0.05(5 \%)$ in the Ha area. As such, Ho was rejected, and Ha received an interest in coding learning to influence the learning outcomes of the XI class students in the subjects of web programming and mobile devices at SMK Negeri 8 Semarang.

The results of this study are relevant to the various theories expressed by the previous researchers. The most critical factor in studying programming about students is their interest in programming; In addition to their presence factors in class and also their perception of programming (coding) [1]. Interest is at least indirectly associated with learning outcomes and achievements even when controlling previous abilities and usually contributing about $10 \%$ of performance variances [26]. The results of the study itself are statements of what students know, understood, and able to do them after finishing the study [16].

Interest is a significant thing to facilitate the learning process [6]. It is by the opinions of Dewey saying that interest is essential for learning to be satisfying and enjoyable, and also research has confirmed that interest predicts intrinsic motivation for learning outcomes and have a positive effect [8].

Learning interests have an essential role in determining the primary learning outcomes to facilitate the learning process that also affects learning outcomes. The growing interest in someone will pay attention to doing something diligently for an extended period, more concentrated, easy to remember, and not easily bored with what does learn.

Programming is not only a hierarchical skill but also a double skill. Programming is a process that starts with translating an algorithm into the program's code. The hardest part is translating the requirement specifications into the algorithm. The right algorithm will produce the right program. Therefore, students are required to be skilled in all processes; Designing algorithms, translating algorithms into program code, and writing program code with the correct syntax. Learning programming will be tedious and difficult if they are not interested in the subject. The way teachers lead the class can also be a factor that makes students not interested in the subject. Different students have different types of motivation. Some students are motivated to learn to program because of their interests while others are motivated by their parents or friends [15].

The study of Mazer shows a positive relationship between the interests and the emotional and cognitive involvement of students into the learning process, which also affects the learning outcomes [24]. On the other hand, it examines how types of questions (True or false, double choice, calculations, or essays) used in judgment and level pressure will affect student learning 
outcomes [25]. In addition to student learning interests, student study hours, and teacher teaching attitudes both have a significant interactive influence on learning outcomes [28].

It is by the conditions in the field that following the purpose of this research is to know the general description of whether there is an influence of learning interest in coding the students ' learning outcomes. The interest in learning to code in the class XI Software Engineering students has a moderate average of 73.57 and the average learning result of 68.57 , which belongs to the high category. Moreover, with the test results, it can be said that the two variables have an influence of each other which is $43.90 \%$, while the remaining of $56.10 \%$ is influenced by other variables or factors that are not included in the This research.

Student learning outcomes is not the only factor that affects learning outcomes but is influenced by other factors, as the way teachers lead the class. So that even if students do not initially have a particular interest in programming materials, but because of the motivations given by teachers who ultimately make students more active in the learning process so that they have better learning outcomes [28].

The results showed that there was a donation of interest in learning coding of $43.90 \%$ on the outcome of learning already relevant to the theory that interest in learning is one of the factors affecting the outcome of learning and positive effect [1] [26] as Dewey's opinion [8] with a result of $43.90 \%$ showing the learning of coding interest can be said have a substantial contribution to the outcome of learning because $56.10 \%$ of the other factors are influenced by other variables such as class attendance and student perception.

In addition there is also the role of emotional and cognitive involvement, students learning hours and teacher teaching attitudes and also the types of problems that are given when the assessment affects learning outcomes, that also relevant to the theory [24] [28] [25]. So it can also be said that in this study, interest has a more significant influence on the outcome of learning compared with previous research, which only affects by $10 \%$.

\section{Conclusion}

Based on the results of the hypothesis test using simple linear regression analysis, it is inferred that the results of this study were an influence on the interest in learning to code in the learning outcomes of the Web programming and mobile device class XI in SMK Negeri 8 Semarang. According to the table ANOVA, F is calculated as 25.785 and probability (Sig.) 0.000 , which means smaller than the equivalent of 0.05 significance, or Sig. $0,000<0.05$, so that it can be taken to decide that variable interest learns coding students Influence of student learning outcomes, which means that Ho is rejected and $\mathrm{H} \alpha$ is accepted.

Referring to the results of data analysis with regression calculations can be concluded that the learning interest variables have contributed to $43.90 \%$ of the variable changes in student learning outcomes, while the remaining of $56.10 \%$ is influenced by other factors not mentioned in this study. A donation of learning-coding interest of $43.90 \%$ of the student's learning results is quite significant. It means that in order to improve students ' learning outcomes is not merely enough by increasing the interest in learning to code in the students, they also fix the learning process and other supporting activities.. 


\section{References}

[1.] Akinola, O. S., \& Nosiru, K. A. (2014). Factors Influencing Students' Performance In Computer Programming: A Fuzzy Set Operations Approach. International Journal Of Advances In Engineering \& Technology, 7(4), 1141-1149.

[2.] Cooper, K. M., Downing, V. R., \& Brownell, S. E. (2018). The influence of active learning practices on student anxiety in large-enrollment college science classrooms. International Journal of STEM Education 5 (1), 23.

[3.] Effendi, M. (2013). Integrasi Pembelajaran Active Learning dan Internet-Based Learning dalam Meningkatkan Keaktifan dan Kreativitas Belajar. Nadwa | Jurnal Pendidikan Islam, 7(2), 283308.

[4.] Fuad, Z. A. dan Zuraini. (2016). Faktor-faktor yang Mempengaruhi Minat Belajar Siswa Kelas 1 SDN 7 Kute Panang. Jurnal Tunas Bangsa 2 (3).

[5.] Hidayat, A. (2013, January 4). Pengertian dan Tutorial Uji Heteroskedastisitas dengan Uji Glejser. Retrieved from Statistikian: https://www.statistikian.com/2013/01/ujiheteroskedastisitas.html

[6.] Jamilah, \& Isnani, G. (2017). The Influence of Classroom Climate, Learning Interest, Learning Discipline and Learning Motivation to Learning Outcomeson Productive Subjects. Jurnal Pendidikan Bisnis dan Manajemen 02, 3, 85-96.

[7.] Junanto, S. (2016). Evaluasi Program Pendampingan Pengembangan Kepribadian Muslim Integral (P3KMI) Di Jurusan Pendidikan Guru Raudhatul Athfal Fakultas Ilmu Tarbiyah Dan Keguruan Iain Surakarta Tahun 2016. Jurnal Penelitian, Vol. 10, No. 2.

[8.] Kahu, E., Nelson, K., \& Picton, C. (2017). Student interest as a key driver of engagement for first year students. Student Success, 8(2), 55-66.

[9.] Khodijah, Nyayu. (2017). Psikologi Pendidikan. Jakarta: Rajawali Pers.

[10.] Lolombulan, J. H. (2017). Statistika Bagi Peneliti Pendidikan. Yogyakarta: Andi.

[11.] Nistanto, Reska K. (2015). Menkominfo Ingin Pelajaran "Coding" Masuk Sekolah. Retrieved from Tekno Kompas:

[12.] (https://tekno.kompas.com/read/2015/09/10/13160077/Menkominfo.Ingin.Pelajaran. Coding.Masuk.Sekolah). Desember 17th, 2018.

[13.] Paolini, A. (2015). Enhancing Teaching Effectiveness and Student Learning Outcomes. The Journal of Effective Teaching, 15(1), 20-33.

[14.] Prihadi, Susetyo Dwi. (2015). Satu dari Sepuluh Siswa di Indonesia Ingin Belajar Coding. Retrieved from CNN Indonesia: (https://www.cnnindonesia.com/teknologi/2015032805424518542518/satu-dari-sepuluh-siswadi-indonesia-ingin-belajar-coding). Desember 17th, 2018.

[15.] Priyanto, S. (2013). Metodologi Penelitian Kualitatif. Sidoarjo: Zifatama Publishing.

[16.] Rahmat, M., Shahrani, S., Latih, R., Yatim, N. F., Zainal, N. F., \& Rahman, R. A. (2012). Major problems in basic programming that influence student. Procedia - Social and Behavioral Sciences 59, 287-296.

[17.] Sara Cervai, L. C. (2013). Assessing the quality of the learning outcome in vocational education: the Expero model. Jounal Of Workplace Learning , 198-210.

[18.] Sobari, Fazri. (2017). Pengaruh Minat Belajar Terhadap Hasil Belajar Siswa Pada Mata Pelajaran Ilmu Pengetahuan Sosial di SMP Negeri 1 Jonggol. Jakarta: UIN Syarif Hidayatullah.

[19.] Subana, M., \& Sudrajat. (2005). Dasar-Dasar Penelitian Ilmiah. Bandung: Pustaka Setia.

[20.] Sugiyono. (2016). Metode Penelitian Kuantitatif, Kualitatif, dan R\&D. Yogyakarta: Alfabeta.

[21.] Sujarwanta, Agus dkk. (2017). Studi Ex Pos Facto Pengaruh Pengalaman Saintifik dan Pengetahuan Lingkungan Terhadap Kepedulian Lingkungan Mahasiswa Pendidikan Biologi Tahun Akademik 2015/2016. Jurnal Lentera Pendidikan Pusat Penelitian LPPM UM Metro, 1 (2).

[22.] Suwardi. (2012). Pengaruh Minat Belajar Terhadap Hasil Belajar Siswa Pada Mata Pelajaran Pendidikan Agama Islam di SMK Negeri 1 Sengkang Kabupaten Wajo. Tesis. Makassar: UIN Alauddin Makassar. 
[23.] Syarowiyah, T. (2016). Pengaruh Metode Pembelajaran Praktik Terhadap Motivasi Dan Hasil Belajar Pendidikan Agama Islam Siswa Kelas IV Sekolah Dasar. STUDIA DIDKATIKA Jurnal Ilmiah Pendidikan 2 (10).

[24.] Taniredja, T. dan Mustafidah, H. (2011). Penelitian Kuantitatif (Sebuah Pengantar). Bandung: Alfabeta.

[25.] Taurina, Z. (2015). Students' Motivation and Learning Outcomes: Significant Factors in Internal Study Quality Assurance System. International Journal for Cross-Disciplinary Subjects in Education (IJCDSE), 5(4), 2625-2630.

[26.] Tetteh, G. A. (2015). Influence of type of assessment and stress on the learning outcomes. Journal Of International Education, 125-144.

[27.] Vainikainen, M.-P., Salmi, H., \& Thunebergb, H. (2015, July). Situational Interest and Learning in a Science Center Mathematics Exhibition. Journal of Research in STEM Education, 1, 15-29.

[28.] Wali, Muhammad dan Ahmad, Lukman. (2017). Perancangan Aplikasi Source code library Sebagai Solusi Pembelajaran Pengembangan Perangkat Lunak. Jurnal JTIK (Jurnal Teknologi Informasi dan Komunikasi) 1 (1)

[29.] Yu-Je Lee, C.-H. C.-Y. (2011). The influences of interest in learning and learning hours on learning outcomes of vocational college students in Taiwan: using a teacher's instructional attitudeas the moderator. Global Journal of Engineering Education, 140-153. 